\title{
VALIDATION OF ANALYTICAL METHOD OF 2,5-HEXANEDIONE ON URINE BY GAS CHROMATOGRAPHY
}

\section{MUCHTARIDI MUCHTARIDI ${ }^{*}$, KURNIA MEGAWATI ${ }^{1}$, FEBRINA AMELIA SAPUTRI ${ }^{1}$, MULYANA M. ${ }^{2}$}

${ }^{1}$ Department of Pharmaceutical Analysis and Medicinal Chemistry, Faculty of Pharmacy, Universitas Padjadjaran, Jl Raya Bandung Sumedang Km 21 Jatinangor, West Java, Indonesia, 45363, ${ }^{2}$ PT. Prodia OHI International, Jalan Kramat Raya No. 148, Central Jakarta 10430, Indonesia

Email: muchtaridi@unpad.ac.id

\section{Received: 19 Feb 2019, Revised and Accepted: 24 May 2019}

\section{ABSTRACT}

Objective: The purpose of this study was to obtain a valid analytical method for determining the level of 2,5-hexanedione in the urine of oil industry workers.

Methods: Gas Chromatography (GC) was employed to analyze 2,5-hexanedione in the urine. The analysis was done using HP-5 (Crosslinked methyl siloxane) capillary columns $30 \mathrm{~m} \times 0.320 \mathrm{~mm}$ long, film thickness $0.25 \mu \mathrm{m}$. The temperature of the detector temperature was $300{ }^{\circ} \mathrm{C}$, and the injector temperature was $250^{\circ} \mathrm{C}$. The helium gas flow rate was $2 \mathrm{ml} / \mathrm{min}$. The detector was Flame Ionization Detection (FID). Parameters of system suitability test and validation were obtained.

Results: This study results that the method of analysis 2,5-hexanedione in urine by Gas Chromatography (GC) confirm the requirements of the validation method with a linearity was 0.99963 , accuracy was in the range of $99.16 \%$ to $114.13 \%$, the precision with $\%$ coefficient of variation was $1.65 \%$ to $5.16 \%$, \% coefficient variation of specificity was $0.027 \%$, limit of detection was $0.054 \mu \mathrm{g} / \mathrm{ml}$ and limit of quantification was $0.18 \mu \mathrm{g} / \mathrm{ml}$.

Conclusion: The proposed GC method meets the acceptance criteria of validation parameters and can be applied for routine analysis.

Keywords: 2,5-hexanedione, Gas chromatography, Hexane, Validation

(C) 2019 The Authors. Published by Innovare Academic Sciences Pvt Ltd. This is an open access article under the CC BY license (http://creativecommons.org/licenses/by/4.0/) DOI: http://dx.doi.org/10.22159/ijap.2019v11i4.32687

\section{INTRODUCTION}

Population growth was increasing rapidly. It led to the birth of the industrialization era. In this era, the development of science and technology was more advanced. One impacts of science and technology is the use of chemicals in many work processes. Currently, various chemicals are widely used in industries, such as food additives, pesticides, metals and compounds, as well as various organic chemicals including organic solvents [1]. One of the most widely used organic solvents in the industry is hexane.

Hexane is a non-polar solvent [2]. Hexane is a very good and cheap solvent. These compounds are found in glue, varnish, paint, and ink. Commercially, hexane is used to extract vegetable oil from various grains such as soybeans and cottonseed. These compounds are also widely used in the pharmaceutical and cosmetic industries [3].

Hexane is very volatile and will be metabolized in the body. The main metabolite of hexane is 2,5-hexanedione [3]. The mice that given 1\% 2,5-hexanedione for $4 \mathrm{w}$ caused neuropathy, systemic toxicity and testicular toxicity [4]. Toxic effects on the nervous system are associated with the bond between the 2,5-hexanedione metabolite with DNA, RNA and important proteins [5].

The body also could deactivate neurotoxic compounds by conjugating with the available hydroxyl groups to glucuronide and sulfate [6]. These conjugates then quickly eliminated in urine and bile. Toxicological studies of Cardona et al. (1966) showed that there was a correlation between exposure of hexane and 2,5-hexanedione in the urine. Therefore, the amount of 2,5-hexanedione in the urine can be used as a biomarker against hexane exposure [7].

2,5-hexanedione can be measured as a free metabolite or as total metabolite after acid hydrolysis. In 2011, the American Conference of Governmental Industrial Hygienists (ACGIH) determined the recommended biological exposure index for total 2,5-hexanedione was $5 \mathrm{mg} / \mathrm{l}$ and for free 2,5-hexanedione was $0.4 \mathrm{mg} / \mathrm{l}$ [8].

The toxic effect of 2,5-hexanedione is related to its concentration, therefore a quantitative 2,5-hexanedione analysis method is required in biological samples. 2,5-hexanedione analysis using HPLC was done by Gori et al. (1995) [9]. However, in the process of analysis required the derivatization process with 2,4-DNPH [10]. Derivatization involves a chemical reaction between an analyte with a reagent to change the physics-chemical properties of an analyte. This process required a longer analysis time. The novelty of this study, the analysis of 2,5hexanedione was done using Gas Chromatography, no derivatization process was required. The method was simple, selective, and sensitive for the determination of 2,5-hexanedione in the urine.

The published analytical methods are often modified to suit the conditions with the equipment and materials available in the testing laboratory. This modification should be validated to ensure proper testing of the method of analysis [11]. Therefore, validation of the 2,5-hexanedione analysis method using gas chromatography is expected to quantify the 2,5-hexanedione level in the urine sample.

\section{MATERIALS AND METHODS}

\section{Materials}

Standard of 2,5-hexanedione (Sigma-Aldrich), dichloromethane (Sigma-Aldrich), sodium sulphate anhydrate (EMSURE®), aquabidest, pooled urine.

\section{Tools}

The tools used in this study were a set of GC (Agilent Technologies®) with Flame Ionization Detector (FID), crosslinked methyl siloxane, centrifugation (Eppendorf AG®), analytical balance scale (Mettler Toledo $囚$ ), spatel, glass vial (Agilent Technologies $®$ ), vortex (Digisystem $\AA$ ), flask, test tube, micropipette 10-100 $\mu$ l and 100-1000 $\mu \mathrm{l}$ (ACURA 825®), and glass tools commonly used in Analytical Laboratory. Data analysis and interpretation using Microsoft Excel 201364 bit software and online GC Software and Agilent Technologies GC offline.

\section{Preparation of standard 2.5-hexanedione}

Standard of 2,5-hexanedione was prepared by dissolved $5 \mathrm{mg}$ standard with $10 \mathrm{ml}$ dichloromethane, Then the standard solution was diluted to obtain the concentration of $0.1 ; 0.2 ; 0.4 ; 1,2 ; 2 \mu \mathrm{g} / \mathrm{ml}$. 


\section{Preparation of pooled urine}

Pooled urine prepared by mixing urine with aquabidest with a ratio of 20:80. The prepared urine is used as a matrix in the analysis by spike method.

\section{Preparation of spiked urine}

Standard of $5 \mathrm{mg}$ 2,5-hexanedione was prepared, then added $20 \mathrm{ml}$ of pooled urine. The solution was diluted to obtain the concentration of $0.1 ; 0.25 ; 0.5$ and $2 \mu \mathrm{g} / \mathrm{ml}$.

\section{GC condition}

The chromatographic system was optimized by injecting $2 \mu \mathrm{g} / \mathrm{ml}$ standard under the following conditions [12]: Columns: HP-5 (Crosslinked methyl siloxane) capillary columns, $30 \mathrm{~m} \times 0.320 \mathrm{~mm}$ long, film thickness $0.25 \mu \mathrm{m}$, detector temperature $300^{\circ} \mathrm{C}$, injector temperature $250^{\circ} \mathrm{C}$, column temperature was programmed from 30 ${ }^{\circ} \mathrm{C}$ to $325{ }^{\circ} \mathrm{C}$. The initial temperature of $30{ }^{\circ} \mathrm{C}$ was held for $3 \mathrm{~min}$, gradually increased to $60^{\circ} \mathrm{C}$ at a rate of $6^{\circ} \mathrm{C} / \mathrm{min}$ and held for $5 \mathrm{~min}$. Then the temperature was increased to $90^{\circ} \mathrm{C}$ at a rate of $15^{\circ} \mathrm{C} / \mathrm{min}$. Helium gas flow rate: $2 \mathrm{ml} / \mathrm{min}$ with detector Flame Ionization Detection (FID) and the injection volume was $1 \mu \mathrm{l}$.

\section{System suitability test}

The system suitability test was performed by injecting a standard solution of $2 \mu \mathrm{g} / \mathrm{ml}$ under optimum conditions. Then determined the Retention Time, Tailing Factor (TF), Resolution (Rs), Number of Theoretical Plate (N), and High-Efficiency Theoretical Plate (HETP) [13].

\section{Validation of analysis method}

Validation methods include linearity, accuracy, specificity, the limit of detection, and limit of quantification [14].

\section{Linearity}

The linearity was determined from the standard curve. Preparation of the standard curves with external standard method by preparing the standard of 2,5 -hexanedione at concentration 0,$1 ; 0.2 ; 0.4 ; 1,2 ; 2$ $\mu \mathrm{g} / \mathrm{ml}$.

\section{Accuracy}

Accuracy was done by prepare the spike urine solution with 3 different concentrations $(0.1,0.5$, and $2 \mu \mathrm{g} / \mathrm{ml})$. Each concentration was triplicate. Then, determined the recovery. Recovery $(\% \mathrm{CV})$ should be between $80-120 \%$ [14].

\section{Precision}

The precision test was performed by prepare the spike urine solution with 3 different concentrations $(0.25,0.5$ and $2 \mu \mathrm{g} / \mathrm{ml})$. Each concentration was triplicated. The value of precision was expressed by the Relative Deviation Standard (RSD) response. The RSD should be $\leq 2.0 \%$ [14]

\section{Limit of quantification and limit of detection}

Limit of detection (LOD) and Limit of Quantification (LOQ) was obtained by the determination based on the standard deviation and slope. LOD and LOQ were calculated by the following formula [13]:

$$
\begin{aligned}
& \mathrm{LOD}=\frac{3 \times \mathrm{SD}}{\text { slope }} \\
& L O Q=\frac{10 \times S D}{\text { slope }}
\end{aligned}
$$

Note:

$\mathrm{SD}=$ Standard deviation of standard curve intercept

LOD = Limit of Detection

LOQ= Limit of Quantification

\section{Specificity}

Specificity was determined by analyzing a standard solution 0.4 $\mu \mathrm{g} / \mathrm{ml}$ and a spike urine $0.5 \mu \mathrm{g} / \mathrm{ml}$. The specificity was determined by comparing the retention time of the standard 2.5-hexanedione chromatogram and the spike solution chromatogram and then determined the value of coefficient variation [15].

\section{Preparation of test solution}

Test solution was prepared by mixing $2.5 \mathrm{ml}$ of 2,5-hexanedione standard solution with $2.5 \mathrm{ml}$ dichloromethane, then vortex it. The solution was centrifuged at $3000 \mathrm{rpm}$ for $10 \mathrm{~min}$. Its organic phase was taken, then $500 \mathrm{mg}$ of anhydrous sodium sulphate was added. It was centrifuged again at $3000 \mathrm{rpm}$ for $10 \mathrm{~min}$. Take the dichloromethane phase. Inject to GC-FID.

\section{RESULTS AND DISCUSSION}

\section{Preparation of pooled urine}

Pooled urine preparation needs to be done because the urine pooled will be used as a matrix for spike solutions. Pooled urine was made by mixing urine with aquabidest with a ratio of 20:80.

\section{Preparation of spiked urine}

Spike urine preparation was used for the analysis of validation parameters such as accuracy, precision, specificity and system suitability testing. Spike urine preparation was done by added the standard into the pooled urine to obtain the required various concentration for the analysis. Urine was spiked into several concentrations of $0.1 ; 0.25 ; 0.5$ and $2 \mu \mathrm{g} / \mathrm{ml}$.

\section{Optimization of GC condition}

The optimum condition of GC for 2,5-hexanedione was using column temperature programmed at $30{ }^{\circ} \mathrm{C}-325{ }^{\circ} \mathrm{C}$ and helium gas flow rate in column $2 \mathrm{ml} / \mathrm{min}$. Used also $\mathrm{H}_{2}$ gas to heat the FID detector.

\section{System suitability test}

System suitability test was a series of experiments conducted to ensure that a method will produce acceptable accuracy and precision. The chromatogram of an analyte using the optimum condition can be seen at fig. 1 .

The parameters used to determine the suitability of the system in this study include retention time (RT), theoretical plate (N), highefficiency theoretical plate (HETP), tailing factor (TF) and resolution (Rs) in standard solution 5 times [13]. From the system suitability test, the CV RT, N, HETP, and RS values appropriated with the system suitability parameters. The result of the system suitability test can be seen in table 1 .

\section{Validation of the analytical method}

Validation of the analytical method was used to ensure that the methods used corresponding with the requirements in use so that the results obtained are acceptable and reliable. In this research, the validation parameters used are linearity, accuracy, precision, the limit of detection, the limit of quantification, and specificity [16].

\section{Linearity}

Linearity test results obtained from the equation of 2,5-hexanedioe calibration curve $y=4.0526 x+0.0787$ with the value of correlation coefficient 0.99963 . Analysis method was valid if linearity parameter was $>0.99$ [15].

\section{Accuracy}

The accuracy of an analytical procedure describes the closeness between the measured value and the value received either the convention value or the reference value, or the actual value [13]. The calculation of \% recovery can be seen in table 2 . 


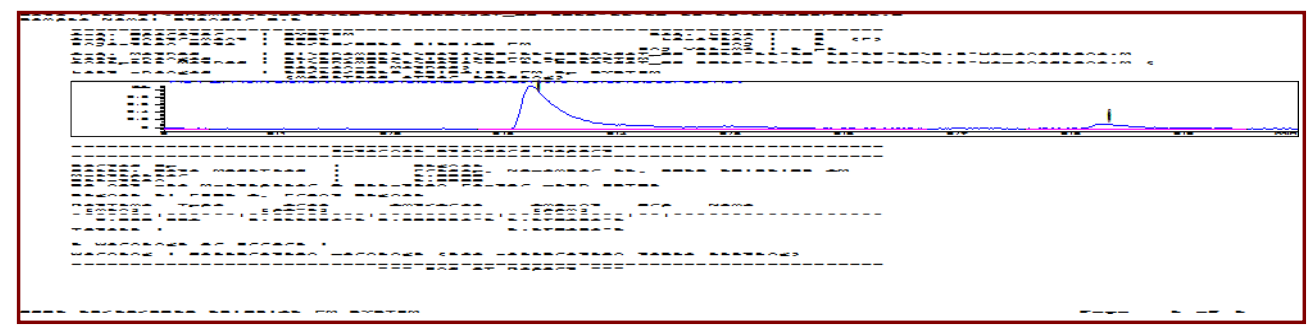

(a)

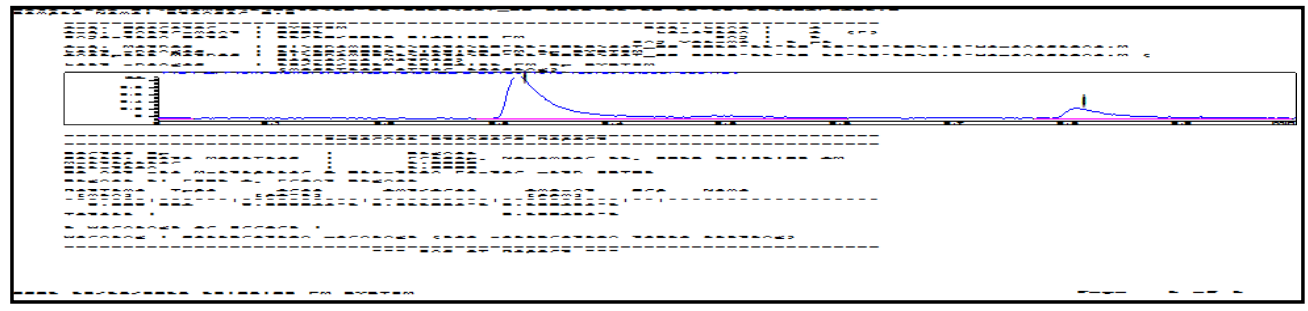

(b)

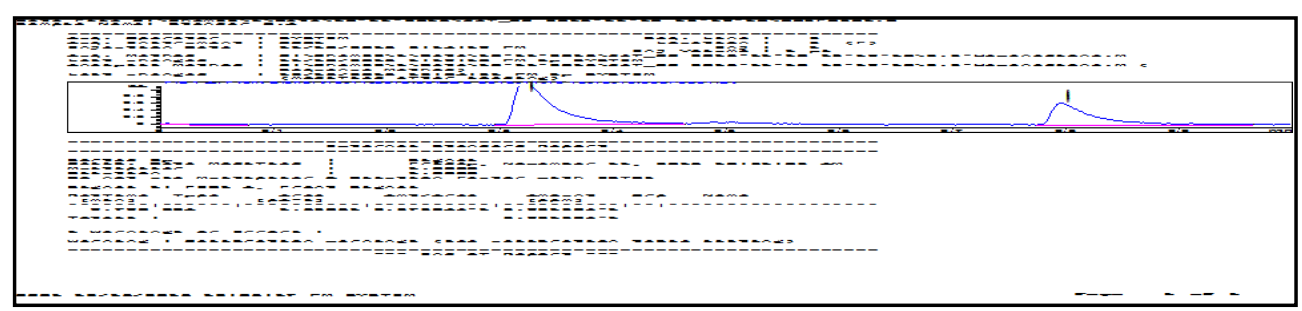

(c)

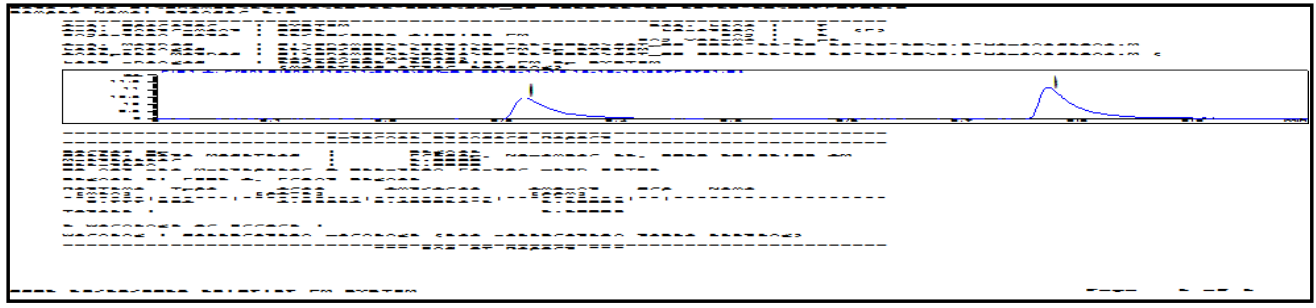

(d)

Fig. 1: Chromatogram of 2,5-hexanedione with concentration (a) $0,1 \mu \mathrm{g} / \mathrm{ml}$ (b) $0,2 \mu \mathrm{g} / \mathrm{ml}$ (c) $0,4 \mu \mathrm{g} / \mathrm{ml}(\mathrm{d}) 1,2 \mu \mathrm{g} / \mathrm{ml}$

Table 1: System suitability test results

\begin{tabular}{ll}
\hline Parameters & Results \\
\hline \% CV RT & $0.013+0.001$ \\
N & $806388.60+68.89$ \\
HETP & $0.00372+0.0008$ \\
TF & $3.20+0.54$ \\
Rs & $13.231+2.34$ \\
\hline
\end{tabular}

Number of experiments = 5, Note: CV: Coefficient variation, RT: Retention time, N: Number of Theoretical Plate, HETP: High-Efficiency Theoretical Plate, TF: Tailing factor, Rs: Resolution

Table 2: Accuracy test results

\begin{tabular}{|c|c|c|c|}
\hline Theoritical concentration $(\mu \mathrm{g} / \mathrm{ml})$ & Recovery $(\mu \mathrm{g} / \mathrm{ml})$ & \% Recovery & Average \% recovery \\
\hline \multirow[t]{3}{*}{0.1} & 0.120 & 120 & $114.13+10.16$ \\
\hline & 0.120 & 120 & \\
\hline & 0.102 & 102.4 & \\
\hline \multirow[t]{3}{*}{0.5} & 0.580 & 116 & $114+07.21$ \\
\hline & 0.600 & 120 & \\
\hline & 0.530 & 106 & \\
\hline \multirow[t]{3}{*}{2} & 2.040 & 102 & $99.16+03.68$ \\
\hline & 1.940 & 95 & \\
\hline & 2.010 & 100.5 & \\
\hline
\end{tabular}

Note: Number of experiments $=3$ 
Accuracy was obtained by calculating the recovery of urine spike solution. The recovery was obtained by calculating the difference between the concentrations of the results obtained with the blanks. The $\%$ recovery in the three concentrations shows that in all three concentration appropriated with the requirements of the accuracy parameter, \% recovery requirement is $80-120 \%$ [15].

\section{Precision}

Precision was a measure of the repetition of a homogenous sample measurement series. This test can be performed by preparing three different concentrations of the target analytical concentration [13]. The results of calculation $\% \mathrm{CV}$ of the test of the precision can be seen in table 3 .

Table 3: Precision test results

\begin{tabular}{llll}
\hline Theoretical concentration $(\mu \mathrm{g} / \mathrm{ml})$ & Measurable $(\boldsymbol{\mu g} / \mathbf{m l})$ & Average & \%CV \\
\hline 0.25 & 0.33 & $0.33+0.0082$ & \\
& 0.34 & $0.57+0.0294$ & \\
0.50 & 0.32 & & \\
& 0.58 & 2.16 & \\
2.00 & 0.60 & $2.00+0.033$ & \\
& 0.53 & & \\
\hline
\end{tabular}

Number of experiments $=3$

The calculation was performed on the concentration obtained from spiked urine. In the test, urine blanks are also measured to know whether there was 2,5-hexanedione content in it or not. Based on the research, the urine blank does not contain 2,5-hexanedione. Based on the results of the research, the \% of the coefficient of variation obtained ranged from 1.65 to $5.16 \%$. The criteria for receiving precision depends on the concentration of the analyte. For unit 1 $\mu \mathrm{g} / \mathrm{ml}$ (ppm), \% CV should not be more than $11 \%$ [13]. Based on these criteria, this study was appropriate with the precision requirement.

\section{Limit of quantification and limits of detection}

Limit of Detection (LOD) indicates the smallest number of analyte in the sample that can give a significant response, while the Limit of Quantification (LOQ) indicates the smallest number of analyte in the sample that can appropriate with the accuracy and precision criteria [14]. Based on the calculation results, the limit of detection was $0.054 \mu \mathrm{g} / \mathrm{ml}$ and the limit of quantification was $0.18 \mu \mathrm{g} / \mathrm{ml}$. Result of LOD and LOQ can be seen in table 4.

Table 4: LOD and LOQ results

\begin{tabular}{|c|c|c|c|c|}
\hline Concentration $(\mu \mathrm{g} / \mathrm{ml})$ & Width Area (y) & Averages & LOD & LOQ \\
\hline \multirow[t]{3}{*}{0.1} & 0.33 & $0.33+0.010$ & 0.054 & 0.18 \\
\hline & 0.32 & & & \\
\hline & 0.34 & & & \\
\hline \multirow[t]{3}{*}{0.2} & 0.34 & $0.34+0.010$ & & \\
\hline & 0.33 & & & \\
\hline & 0.35 & & & \\
\hline \multirow[t]{3}{*}{0.4} & 0.32 & $0.32+0.005$ & & \\
\hline & 0.33 & & & \\
\hline & 0.32 & & & \\
\hline \multirow[t]{3}{*}{1.2} & 0.58 & $0.58+0.010$ & & \\
\hline & 0.57 & & & \\
\hline & 0.59 & & & \\
\hline \multirow[t]{3}{*}{2} & 0.60 & $0.60+0.015$ & & \\
\hline & 0.62 & & & \\
\hline & 0.59 & & & \\
\hline
\end{tabular}

Number of experiments $=3$

Table 5: Specificity test results

\begin{tabular}{ll}
\hline Concentration & Retention time (min) \\
\hline Standard $(0.4 \mu \mathrm{g} / \mathrm{ml})$ & 9.798 \\
Standard $(0.4 \mu \mathrm{g} / \mathrm{ml})$ & 9.801 \\
Standard $(0.4 \mu \mathrm{g} / \mathrm{ml})$ & 9.807 \\
Spike $(0.5 \mu \mathrm{g} / \mathrm{ml})$ & 9.803 \\
Spike $(0.5 \mu \mathrm{g} / \mathrm{ml})$ & 9.801 \\
Spike $(0.5 \mu \mathrm{g} / \mathrm{ml})$ & 9.801 \\
Average & 9.801 \\
SD & 0.002 \\
\% CV & 0.027 \\
\hline
\end{tabular}

Number of experiments $=3$

\section{Specificity}

Specificity tests were performed to know the appropriateness of an analyte in the presence of other components in the sample matrix, such as impurities, product degradation, and matrix components. The results of the specificity test can be seen in table 5 .
Table 5 shows $\%$ CV of the standard and spike solution was $0.027 \%$. It shows that there was no significant change. Therefore, this method can be used as a specific analysis for 2,5-hexanedione.

The proposed method gives a simple and sensitive method for the determination of 2,5-hexanedione. The previous methods need the 
derivatization process. Maestri et al. [17] had used dansyl hydrazine; 1,3-diacetyl benzene (1,3-DAB) to react with 2,5-hexanedione before analyzed using high-performance liquid chromatography with fluorescence detection. Gori et al. [9] has developed the analytical method for the determination of 2,5-hexanedione with acid hydrolysis and derivatization step using 2,4-dinitrophenylhydrazine at $70{ }^{\circ} \mathrm{C}$ for $20 \mathrm{~min}$. Moreover, the detection limit from this study was $0.054 \mu \mathrm{g} / \mathrm{ml}$, was more sensitive than the previous study from Fedtke and Bolt [12] that was $0.12 \mu \mathrm{g} / \mathrm{ml}$.

\section{CONCLUSION}

The optimum condition for the analytical method of 2,5hexanedione by GC (Gas Chromatography) was carried out by using HP- 5 (crosslinked methyl siloxane) capillary columns, $30 \mathrm{~m}$ x 0.320 $\mathrm{mm}$ long, film thickness $0.25 \mu \mathrm{m}$, detector temperature was $300^{\circ} \mathrm{C}$, injector temperature $250^{\circ} \mathrm{C}$, column temperature was programmed from $30^{\circ} \mathrm{C}$ to $325^{\circ} \mathrm{C}$. The helium gas flow rate was $2 \mathrm{ml} / \mathrm{min}$, and the injection volume was $1 \mu \mathrm{L}$

\section{ACKNOWLEDGMENT}

The authors acknowledge the facilities from PT. Prodia OHI.

\section{AUTHORS CONTRIBUTIONS}

All the author have contributed equally

\section{CONFLICT OF INTERESTS}

Declared none

\section{REFERENCES}

1. Rusdy MDR. Neurotoxic symptoms analysis due to exposure of xylene organic solvents to paint making workers in company X in 2012. Depok: University of Indonesia; 2012.

2. Maulida D, Zulkarnaen N. Antioxidant extraction (Lycopene) from tomato fruit using mixed solvents of $\mathrm{N}$-hexane, acetone and ethanol. Semarang: Universtas Diponegoro; 2010.

3. Cheng X, Wang G, Ma Z, Chen Y, Fan, Jing-Jing, et al. Exposure to 2,5-hexanedione can induce neural malformations in chick embryos. NeuroToxicol 2012;33:1239-47.

4. Kim Boekelheide. 2,5-Hexanedione alters microtubule assembly. I. Testicular atrophy, not nervous system toxicity, correlates with enhanced tubulin polymerization. Toxicol Appl Pharmacol 1987;88:370-82.

5. De Caprio AP, O'Neil EA. Alterations in rat axonal cytoskeletal proteins induced by in vitro and in vivo 2,5-hexanedione exposure. Toxicol Pharmacol 1985;78:235.
6. Couri D, Milks M. Toxicity and metabolism of the neurotoxic hexacarbons $n$-hexane, 2-hexanone and 2,5-hexanedione. Annu Rev Pharmacol Toxicol 1982;22:145-66.

7. Cardona A, Marhuenda D, Prieto MJ, Marti J, Periago JF, Sanchez $\mathrm{JM}$, et al. Behaviour of urinary 2,5-hexanedione in occupational co-exposure to $\mathrm{n}$-hexane and acetone. Arch Occup Environ Health 1996;68:88.

8. American Conference of Governmental Industrial Hygienist (ACGIH). TLVs and BEIs: Based on the documentation of the threshold limit values for chemical substances and physical agents and biological exposure indices. Cincinnati: OH; 2011.

9. Gori G, Bartolucci GB, Sturaro A, Parvoli G, Doretti L, Troiano $\mathrm{R}$, et al. High-performance liquid chromatographic determination of urinary 2,5-hexanedione as mono-2,4dinitrophenylhydrazone using ultraviolet detection. J Chromatogr B Biomed Appl 1995;673:165-72.

10. Oliveira AFF, Patrícia PP, Maria JN, Paiva, Siqueira ME Determination of 2,5-hexanedione in urine by headspace solidphase microextraction and gas chromatography. J Anal Toxicol 2009;33:223-8.

11. Food and Drug Administration, Guidance for Industry: Bioanalytical Method Validation. Maryland: Food and Drug Administration; 2001. Available from: http://www.fda.gov/downloads/DrugsGuidanceComplianceRe gulatoryInf ormation/Guidance/UCM070107.pdf. [Last accessed on 11 Sep 2016]

12. Fedtke N, Bolt HM. Detection of 2,5-hexanedione in the urine of persons not exposed to n-hexane. Int Arch Occup Environ Health 1986;57:143-8.

13. Harmita. Implementation guidelines for method validation and its calculation. Majalah Ilmu Kefarmasian 2004;1:119-22.

14. Hasanah AN, Musfirah I, Muchtaridi. Basics of physicochemical analysis in the pharmaceutical field. Yogyakarta: Deepublish; 2016.

15. The Association of Analytical Communities (AOAC) International Method Committee Guidelines for Validation of Qualitative and Quantitative Food Microbiological Official Methods of Analysis. J AOAC Int 2002;85:1-5.

16. International Conference on Harmonization, Q2 Validation of analytical procedures text and methodology international conference on harmonization of technical requirements for registration of pharmaceutical for human use, ICH Harmonized Tripartite Guideline, Canada; 2005.

17. Maestri L, Ghittori S, Imbriani M, Capodaglio E. Determination of 2,5-hexandione by high-performance liquid chromatography after derivatization with dansyl hydrazine. J Chromatogr B Biomed Appl 1994;657:111-7. 